\title{
Effects of solar parks on soil quality, CO2 effluxes and vegetation under Mediterranean climate
}

\author{
Quentin Lambert ${ }^{1}$, Armin Bischoff ${ }^{1}$, Alexandre Cluchier ${ }^{2}$, Sixtine Cueff $^{3}$, and Raphael \\ Gros $^{1}$ \\ ${ }^{1}$ Institut Méditerranéen de Biodiversité et d'Écologie Marine et Continentale \\ ${ }^{2}$ ECO-MED \\ ${ }^{3}$ INRAE Ille-de-France-Versailles-Grignon
}

June 6, 2021

\begin{abstract}
Solar energy is increasingly used to produce electricity in Europe, but the environmental impact of constructing and running solar parks (SP) is not yet well studied. Solar park construction requires partial vegetation removal and soil leveling. Additionally, solar panels may alter soil microclimate and functioning. In our study of three French Mediterranean solar parks, we analyzed 1) effects of solar park construction on soil quality by comparing solar park soils with those of semi-natural land cover types (pinewood and shrubland) and abandoned croplands (abandoned vineyards); 2) the effect of solar panels on soil microclimate, $\mathrm{CO} 2$ effluxes and vegetation. We measured 21 soil properties of physical, chemical, and microbiological soil quality in one solar park and its surroundings to calculate integrated indicators of soil quality. We surveyed soil temperature and moisture, $\mathrm{CO} 2$ effluxes and vegetation below and outside solar panels of three solar parks. Soil aggregate stability was reduced by SP construction resulting in a degradation of soil physical quality. Soil chemical quality and a general indicator of soil quality were lower in anthropogenic (SP and abandoned vineyards) than in semi-natural (pinewood and shrubland) land cover types. However, differences between abandoned vineyards representing the pre-construction land cover type and solar parks were not significant. Solar panels reduced the soil temperature by $10 \%$ and soil CO2 effluxes by $50 \%$ but did not affect early successional plant communities. Long-term monitoring is needed to evaluate the effects of solar panels on vegetation.
\end{abstract}

Manuscript Title

Effects of solar parks on soil quality, $\mathrm{CO}_{2}$ effluxes and vegetation under Mediterranean climate Authors

Quentin Lambert ${ }^{1 *}$, Armin Bischoff ${ }^{2}$, Sixtine Cueff ${ }^{3}$, Alexandre Cluchier ${ }^{4}$, Raphael Gros ${ }^{1}$

Author's institutional affiliations

1 Aix Marseille Université, Université d'Avignon, IRD, CNRS, Institut Méditerranéen de Biodiversité et d'Écologie marine et continentale (IMBE), Campus l'Etoile, Av. Escadrille Normandie Niémen, 13397, Marseille, Cedex 20, France

2 Aix Marseille Université, Université d'Avignon, IRD, CNRS, Institut Méditerranéen de Biodiversité et d'Écologie marine et continentale (IMBE), IUT Avignon, Agroparc, BP 61207, 84911 Avignon Cedex 9, France

3 INRAE, AgroParisTech, UMR ECOSYS, 78850 Thiverval-Grignon, France 
4 ECO-MED Ecologie \& Médiation, Tour Méditerranée, 65 avenue Jules Cantini, 13298 Marseille cedex 20, France

Corresponding author:qntnlmbrt@gmail.com

Short informative containing containing the major key words.

Effects of solar parks on soil quality, CO2 effluxes and vegetation under Mediterranean climate Solar parks are expanding in Europe, but their impact on soil and vegetation is not well studied yet. We have shown in this study, carried out in 3 parks in the Mediterranean region, that the construction of solar parks reduces the physical quality of the soil that could alter main soil function. Moreover, the presence of solar panels decreases $\mathrm{CO} 2$ emissions and temperature but does not change the structure of plants communities.

Short running title

Effects of solar parks on soil quality, $\mathrm{CO} 2$ effluxes and vegetation

Acknowledgements

Q.L acknowledges the French Agency for Environmental Transition (ADEME) for his PhD ground. This work was supported by the program PIESO (ADEME, agreement $\mathrm{N}^{\circ} 1405 \mathrm{C} 0035$ ). The authors which to thanks Pierre Illac and Marine David (Total Quadran) for their contribution to this project. Authors thanks Mathilde Dionisi, Jean Bigotte, Xavier Fortuny, Lisa Foli for their very useful technical assistance in the lab or in the field.

Abstract and Keywords

Abstract:

Solar energy is increasingly used to produce electricity in Europe, but the environmental impact of constructing and running solar parks (SP) is not yet well studied. Solar park construction requires partial vegetation removal and soil leveling. Additionally, solar panels may alter soil microclimate and functioning. In our study of three French Mediterranean solar parks, we analyzed 1) effects of solar park construction on soil quality by comparing solar park soils with those of semi-natural land cover types (pinewood and shrubland) and abandoned croplands (abandoned vineyards); 2) the effect of solar panels on soil microclimate, $\mathrm{CO}_{2}$ effluxes and vegetation. We measured 21 soil properties of physical, chemical, and microbiological soil quality in one solar park and its surroundings to calculate integrated indicators of soil quality. We surveyed soil temperature and moisture, $\mathrm{CO}_{2}$ effluxes and vegetation below and outside solar panels of three solar parks. Soil aggregate stability was reduced by SP construction resulting in a degradation of soil physical quality. Soil chemical quality and a general indicator of soil quality were lower in anthropogenic (SP and abandoned vineyards) than in semi-natural (pinewood and shrubland) land cover types. However, differences between abandoned vineyards representing the pre-construction land cover type and solar parks were not significant. Solar panels reduced the soil temperature by $10 \%$ and soil $\mathrm{CO}_{2}$ effluxes by $50 \%$ but did not affect early successional plant communities. Long-term monitoring is needed to evaluate the effects of solar panels on vegetation.

Keywords: renewable energy, soil functions, land cover, microclimate, soil respiration, plant communities

Main text

Introduction

The use of solar energy to produce electricity is increasingly common in Europe and requires large areas in order to be cost-effective (Murphy et al., 2015 ; Ong et al., 2013). Solar park construction involves clearing and grading the soil surface, burying of electric cables, vegetation removal and soil compaction increasing runoff and erosion. Grading, compaction, and erosion change the physical and chemical properties of the soil and thus reduce its quality. Since solar park construction destroys the vegetation and affects the soil, a careful analysis of the environmental impact of solar parks is needed (Armstrong et al. , 2016; Hernandez et al. , 2015). To our knowledge, analyses of soil quality have not yet been included in studies on the impact 
of solar park construction although soil quality is an important indicator of ecosystem functioning. After the installation of solar panels, the vegetation is regularly mown or grazed limiting vegetation height to prevent shading of panels. The solar panels also change the microclimate such as temperature, humidity, solar radiation (Tanner et al. , 2020; Armstrong et al. ,2016). Such changes in microclimate may affect soil processes and plant communities under panels, in particular in the European Mediterranean with high solar irradiation compared to temperate regions.

Soil quality is "the capacity of a specific kind of soil to function, within natural or managed ecosystem boundaries, to sustain plant and animal productivity, maintain or enhance water and air quality and support human health and habitation" (Karlen et al. , 1997). Three soil quality indicator groups are commonly used: physical, chemical and biological soil properties (Bunemann et al., 2018 ; Costantini et al., 2016 ; Maurya et al., 2020). Physical properties, such as bulk density and texture influence water holding capacity and plant communities by modulating root growth (Scarpare et al. 2019 ; Lampurlanes, Cantero-Martinez 2003). Chemical properties such as inorganic $\mathrm{N}$, total $\mathrm{C}$ and $\mathrm{pH}$ control plant nutrition and microbiological activity. Biological indicators include the activity of decomposers such as invertebrates or microorganisms. These organisms control organic matter decomposition and nutrient cycling (Maurya et al. , 2020).

(Velasquez et al. , 2007) developed a single general indicator of soil quality (GISQ) that integrates a set of physical, chemical and biological soil properties. Such soil properties are chosen and measured to evaluate multifaceted aspects of soil functions and further combined to calculate sub indicators of physical quality, chemical fertility, and biological functioning. The GISQ combines the sub indicators to provide a global assessment of soil quality based on soil ecosystem services and facilitates the comparison of soils between different sites/habitats. In a comparative study on four land use types, (Raiesi \& Salek-Gilani, 2020) showed, using an adapted GISQ, that soil quality was 1.5 times lower in anthropogenic than in natural soils. Joimel et al. (2016) observed a decrease in soil physico-chemical quality along an anthropization gradient from forest to urban soils whereas Joimel et al. (2017) did not find any difference in biological quality of these soils. The construction of solar parks on natural and semi-natural land use types (e.g. forest, shrubland, abandoned vineyards) may reduce soil quality and affect ecosystem functions such as infiltration and storage of water, fertility and plant reestablishment, soil organic matter and nutrient cycling (Khare \& Goyal, 2013; Romero-Diaz et al. , 2017; Rutgers et al. , 2009; Scarpare et al. , 2019; Yin et al. , 2020).

Plant communities and soil functioning may also be affected by changes in microclimate under solar panels. Solar panels reduce solar radiation, air humidity and soil temperatures, but in winter, soil temperatures are generally higher under panels (Armstrong et al., 2016). Adeh et al. (2018) reported highest soil moisture and local heterogeneity of soil water conditions under solar panels. Such changes in microclimate may alter plant community composition and soil respiration that can be measured as $\mathrm{CO}_{2}$ release. Mediterranean plant communities are dominated by heliophilous plants (Bagella \& Caria, 2012). The reduction of solar radiation under solar panels may thus result in a plant community shift towards shade-tolerant species. Seed germination of Mediterranean species may be limited by light reduction (Gresta et al. , 2010) and the mortality of heliophilous plants increases in competition to shade-tolerant species. (Novaraet al. , 2012; de Dato et al. , 2010). The change in air and soil microclimate under panels reduced the soil respiration under temperate oceanic climate (Armstrong et al. , 2016). Under Mediterranean climate with higher annual temperatures and summer drought, changes in microclimate under solar panels may be higher resulting in a strong disturbance of seasonal soil respiration dynamics (Gonzalez-Ubierna \& Lai, 2019). Plant communities also contribute to soil $\mathrm{CO}_{2}$ release by respiration of roots and rhizosphere microorganisms (Raich \& Tufekciogul, 2000) but also by changes in soil structure (Yang et al. , 2009; Zou et al. , 2005). Furthermore, plants are the principal carbon source of decomposer microorganisms (Wall et al. , 2012). Thus, solar panels may also change soil conditions indirectly by a shift in plant community composition since plants are very sensitive to change in microclimate.

The aims of our study were to assess 1) the effect of solar park construction on soil quality in comparing solar parks with semi-natural land cover types (pinewood and shrubland) and abandoned cropland (i.e. abandoned vineyards) and 2) the effects of solar panels on soil microclimate, $\mathrm{CO} 2$ effluxes and vegetation 
under Mediterranean climate. We expected that 1) solar park construction reduces physical, chemical, and biological soil quality, 2) solar panels change soil microclimate and plant community composition, and 3) solar panels change soil respiration according to the season.

2. Materials and Methods

\subsection{Study sites}

Two studies were conducted in three solar parks (SP) located in Southern France (La Calade, PouzolsMinervois and Roquefort des Corbieres) with a distance of 10 to $30 \mathrm{~km}$ from one another (Table 1). These SP were constructed in 2011, 2014 and 2016, respectively, covered between 8.5 and 16 Ha and used groundfixed photovoltaic (PV) systems carrying the solar panels at a fixed inclination. The solar panels are aligned to form rows (height of $0.6 \mathrm{~m}$ min and $2 \mathrm{~m}$ max) exposed to the South and with a gap of $4 \mathrm{~m}$ between rows. The study region is characterized by typical Mediterranean climate with summer drought and mild, wet winters. The SP are mainly bordered by pine forests (Pinus halepensis ), shrublands and vineyards. Dominant species of these shrublands areQuercus coccifera, Pistacia lentiscus, Rosmarinus officinalis, Myrtus communis, Genista scorpius, Brachypodium retusum andCistus monspelliensis. The soils of the SPs are characterized by carbonatic pedofeatures (i.e. fine calcareous silty clay soil).

\subsection{Sampling designs}

Study 1: effect of solar park construction

To study the effects of solar park construction on soil quality, four sampling plots ( $50 \mathrm{x} 2 \mathrm{~m}$ ) separated by $100 \mathrm{~m}$ were randomly chosen within the SP at Roquefort des Corbieres (inter-rows between solar panels). Close to this SP, three major land cover types were identified (pinewood, shrubland and abandoned vineyards) and four sampling plots of the same area $(100 \mathrm{~m} 2)$ separated by $400 \mathrm{~m}$ were randomly chosen for each land cover. In March 2016, ten soil samples were randomly collected (10 cm depth) within each plot, mixed to one composite sample per plot. Composite samples were sieved (mesh size: $2 \mathrm{~mm}$ ) prior to analyses. An aliquot of samples was air-dried (1 week, $30 \mathrm{deg}$ ). For each sample, another aliquot was stored at $4 \mathrm{deg} C$ for microbial analyses.

Study 2: effect of solar panels

To study the effect of solar panels on soil respiration, temperature, and moisture and on plant communities, we randomly selected within each of the $3 \mathrm{SP}$ four sampling plots $(50 \times 2 \mathrm{~m})$ below the solar panels, both separated by at least $100 \mathrm{~m}$, and four adjacent sampling plots $(50 \times 2 \mathrm{~m})$ in the inter-rows between the solar panel.

2.3. Measurements of soil physico-chemical and microbiological quality

Soil physical properties

Water content (g. $\mathrm{kg}^{-1}$ ) was determined after drying samples (24 hours, 105degC). Water holding capacity (WHC) was analyzed according to Saetre (1998) but using a modified protocol. 10g of dried soil were weighted in a PVC cylinder and saturated with water. WHC was defined as the water content remaining in the soil after $12 \mathrm{~h}(4 \mathrm{degC})$. The different soil fractions (i.e. sand, silt, clay) were determined using the Robinson's pipette method (Olmstead et al. , 1930) after organic matter removal by oxidation with $\mathrm{H}_{2} \mathrm{O}_{2}$ (30\%, 48 hours). Bulk density (BD) was determined by measuring dried soil mass sampled in a Siegrist's cylinder. According to Huang et al., (2004), a value of $2.65 \mathrm{~g} . \mathrm{cm}^{-3}$ was assumed for real soil density (RD). Soil porosity was calculated using the following equation.

Soil porosity $=100 \times \frac{R D-B D}{\mathrm{RD}}($ Equation. 1$)$

Mean weight diameter (MWD) of soil aggregates was measured according to Kemper and Rosenau (1986). 


\section{Soil chemical properties}

The soil pH was measured in distilled water and KCL (1M) (Aubert, 1978). Total Carbon (TC) and Nitrogen (TN) content were determined by combustion in an elemental analyzer CN FlashEA 1112 (ThermoFisher) (NF ISO 10694, NFISO 13878). Calcium carbonate (CaCO3) content was measured using a Bernard calcimeter (Muller \& Gastner, 1971) and the percentage of $\mathrm{C}$ in $\mathrm{CaCO} 3$ (C-CaCO3) was determined as: C-CaCO3 $=11.991 / 100 \times$ CaCO3. Inorganic nitrogen $\left(\mathrm{NH}_{4}{ }^{+}\right.$and $\left.\mathrm{NO}_{3}{ }^{-}\right)$was extracted in KCL solution (1M) and analyzed calorimetrically using the nitroprusside-salicylate and nitrosalicylic acid method according to Mulvaney (1996) and Keeney and Nelson (1983), respectively.

Soil microbiological properties

Microbial Biomass (MB) was measured using substrate induced respiration (SIR) rates (Anderson and Domsch, 1978). Basal respiration was determined without adding glucose and was estimated to calculate the metabolic quotient $\mathrm{qCO}_{2}$ (the ratio of basal respiration to microbial biomass), which is a sensitive ecophysiological indicator of soil stress (Anderson, 2003). Three enzyme activities (i.e.fluorescein diacetate hydrolase, phosphatase and tyrosinase) involved in carbon and phosphorous cycles were assessed ( $\mathrm{n}=3$ per sample) to determine the catabolic potential of microbial communities. Fluorescein diacetate hydrolase (FDase, ${\mathrm{U} . \mathrm{g}^{-1}}^{-1}$ dry weight) was measured according to Green et al. (2006), phosphatase (U.g ${ }^{-1}$ dry weight) according to Tabatabai and Bremner (1969) and the activity of tyrosinase $\left(\mu \mathrm{mol} \cdot \mathrm{min}^{-1} \cdot \mathrm{g}^{-1}\right.$ dry weight) according to Saiya-Cork et al. (2002).

\subsection{Measurements of solar panel effects on soil moisture, temperature and in situ respiration}

Soil respiration, temperature and moisture were recorded in March and June 2017 in each sampling plot of the study on solar panel effects.In situ $\mathrm{CO}_{2}$ release $\left(\mathrm{g} \mathrm{CO}_{2} \mathrm{~m}^{-1} \mathrm{~h}^{-1}\right)$ from soils, plants roots, soil organisms and chemical oxidation of $\mathrm{C}$ compounds was measured after removal of aboveground vegetation, using a portable gas analyser (IRGA, EGM-4, PP-system). The device was connected to a closed soil respiration chamber (SRC-1, PP systems Massachusetts, USA). To prevent leakage of $\mathrm{CO}_{2}$ when placing the chamber on the soil, a PVC tube $(10 \mathrm{~cm} \times 11 \mathrm{~cm})$ was buried $1 \mathrm{~cm}$ deep into the soil prior to measurements. Soil temperature was recorded in a depth of $7 \mathrm{~cm}$ using the soil temperature probe (STP-1, PP-system) connected to the respirometer. Soil moisture was recorded on four points at $7 \mathrm{~cm}$ depth using a portable time-domain reflectometry (TDR) device (Delta-T Devices, ML2 Theta Probes).

\subsection{Measurements of solar panel effects on vegetation}

In the sampling plots of the study on solar panel effects, vegetation surveys were carried out in 2016 and 2017. Three rectangular sub-plots of $10 \mathrm{~m}^{2}(2 \mathrm{~m} \times 5 \mathrm{~m})$ were placed at the ends and the center of each plot. Percentage cover of all occurring vascular plant species was estimated as the vertical projection of aboveground plant organs. A ratio of shadow-tolerant (sciaphilous) to hemi-heliophilous and heliophilous plant species (Julve, 2020) was calculated .

\subsection{Statistical analyses}

We calculated a General Indicator of Soil Quality (GISQ) according to Velaquez et al. (2007). Information on 21 variables of physical, chemical, and microbiological soil properties was used to create three subindicators related to main soil functions: 1) physical properties that determine the infiltration and storage of water, 2) chemical properties that affect fertility and plant reestablishment in solar parks, 3) microbiological properties that drive soil organic matter decomposition and nutrient cycling. For each group of variables (physical, chemical and microbiological), a principal component analysis (PCA) with data scaled to unit of variance was run using "FactoMineR" (Husson et al. , 2020) and "Factoextra" (Kassambara \& Mundt, 2020) packages. A synthetic index of quality for each group of variables at a plot i $\left(\mathrm{Iq}_{\mathrm{i}}\right)$ was calculated as the sum of $\mathrm{n}$ variables (vi) multiplied by their respective weight (wi) in the determination of axes 1 and 2 of the PCA (Equation 2.). 
$\mathrm{Iq}_{i}=\sum_{i=1}^{n} w_{i} v_{i}$ (Equation2.)

The values of $\mathrm{Iq}_{\mathrm{i}}$ were then reduced to a common range, between 0.1 and 1.0, using an homothetic transformation to obtain the sub-indicators of physical, chemical and microbiological soil quality (hereafter pSQ, cSQ and mSQ respectively, Equation 3.). In this equation, a is the maximal and $\mathrm{b}$ the minimal Iq value for the plot i.

$p$, c or $m S Q=0.1+\frac{\mathrm{Iq}_{i}-b}{\mathrm{Iq}_{i}-a} \times 0.9$ (Equation 3.)

Finally, a PCA was run with the 3 sub-indicators. The GISQ was obtained by summing the products of the respective contributions of variables to factors 1 and 2 by the $\%$ inertia explained by factors, respectively. Finally, the sum of these products gave the following formula for the GISQ (Equation 4.):

$G I S Q=0.29 p S I q+0.28 c S I q+0.33 m S I q$ (Equation 4.)

All data were analyzed using $\mathrm{R}$ software (3.6.1,R Core (Team, 2020)). Effects of land cover type on soil physical, chemical and microbiological properties, sub-indicators of soil quality and GISQ were assessed using one way-analysis of variance (ANOVA). In the case of a significant land cover type effect, a Tukey HSD post hoc test was used to analyze differences between specific land cover types. To analyze the effect of solar panels on soil temperature, water content, $\mathrm{CO} 2$ effluxes and vegetation, linear mixed-effect models (LMMs) (R package "lme4") were applied including month and treatment (below vs outside panels) as fixed factors and solar park identity as random factor. When necessary, data were transformed using the "bestNormalize" package (Peterson, 2019) to meet the assumptions of normality and homoscedasticity of variances. Effects of solar panels on plant communities were visualized by non-metric multidimensional scaling (nMDS) based on the Bray-Curtis dissimilarity. Differences in plant community composition were tested using permutational multivariate analysis (PERMANOVA) in R package "vegan" (Oksanen et al. , 2019).

3. Results

3.1. Effects of solar park construction on soil properties

Seven of the eight tested physical soil properties were significantly different between land cover types (Table 2). Among these seven properties, only two showed a significant difference between the two semi-natural (pinewood and shrubland) land cover types and the SP. Soil water content was $5.5 \%$ lower in the SP (p $<0.01)$ than in shrubland. The mean weight diameter of aggregates was twice as high in abandoned vineyard as in SP, and three times higher in pinewood and shrubland than in SP $(\mathrm{p}<0.001)$. Organic carbon was about 2.5 times higher in semi-natural than in anthropogenic land cover types $(\mathrm{p}<0.001)$. Sand and silt content, soil porosity and bulk density were significantly different between abandoned vineyard and pinewood (Table 2). Silt content and soil porosity were 1.4 and 1.3 times lower in abandoned vineyard than in pinewood, respectively. Sand content and BD were about 1.5 times higher in abandoned vineyard than in pinewood. Pinewood and shrubland showed similar physical properties without significant differences.

For most soil chemical properties, SP showed significant differences to pinewood and shrubland but not to abandoned vineyard (Table 2). Total carbon contents were 1,44 times higher in semi-natural land cover types than in antropogenic land cover types $(\mathrm{p}<0.01)$. Organic carbon contents were about 2,76 times higher in semi-natural land cover types than in antropogenic land cover types $(\mathrm{p}<0.01)$. Total nitrogen $(\mathrm{TN})$ content showed the same pattern. TN was twice as high in pinewood and shrubland as in the SP and abandoned vineyard $(\mathrm{p}<0.001)$. The water $\mathrm{pH}$ ranged between 8.02 and 8.11 and showed a small but significant difference between shrubland and abandoned vineyard.

Two microbiological properties were significantly different between land cover types (Table 2). Land cover type had a significant influence on basal respiration $(\mathrm{p}<0.03)$ being two times lower in the SP and abandoned vineyard than in forest and shrubland. The FDAse activity was two times higher in shrubland and pinewood than in the SP and abandoned vineyard. Microbial biomass was twice as low (marginally significant) in SP and abandoned vineyard as in the semi-natural land cover types.

3.2. Effects of solar park construction on soil quality 
The first two axes of the PCA run on physical properties explained $69.94 \%$ of the total variance (see A.1.A). The semi-natural land cover types are separated from the antropogenic soils along the first axis. Silt, water content, water holding capacity and mean weight diameter of aggregates had the highest score on the first PCA axis, while soil porosity was strongly correlated with the second axis (see A.1.A). The highest physical quality index of 0.92 was measured in pinewood and shrubland being two times higher than in abandoned vineyard $(\mathrm{p}<0.001)$. The pSQ (Figure 1A) was two times and four times lower in SP than in the abandoned vineyard and semi-natural land cover types, respectively $(\mathrm{p}<0.01)$.

The first two axes of the PCA used to calculate the sub-indicator of soil chemical quality (cSQ) explained $73.78 \%$ of the total variance (see A.1.B). The semi-natural land cover types are separated from the antropogenic soils along the first axis. Total carbon, organic carbon, total nitrogen and ammonium were most correlated with the first axis and nitrate with the second axis (see A.1.B). With a value of 0.18 , the cSQ was four times lower in the SP and abandoned vineyard than in shrubland and pinewood $(\mathrm{p}<0.001$, Figure $1 \mathrm{~B})$.

The first two axes of the PCA used to calculate the sub-indicator of soil microbiological quality explained $77.19 \%$ of the total variance (see A.1.C). Basal respiration, microbial biomass, FDAse and phosphatase were highly correlated with the first PCA axis, while the $\mathrm{qCO}_{2}$ was correlated with the second one (see A.1.C). The $\mathrm{mSQ}$ was not significantly different between land cover types $(\mathrm{p}=0.95)$ (Figure $1 \mathrm{C}$ ).

The General Indicator of Soil Quality was four times lower in the SP and abandoned vineyard than in the pinewood and shrubland $(\mathrm{p}<0.001)$.

\subsection{Effects of solar panels on soil temperature, water content andin situ $\mathrm{CO}_{2}$ effluxes.}

Soil temperature and water content were significantly different between months ( $\mathrm{p}<0.05$; Figure $2 \mathrm{~A}$ and $2 \mathrm{~B})$. Solar panels significantly decreased soil temperature in March and June (Figure 2A) but did not affect soil water content $(\mathrm{p}=0.79)$. Soil $\mathrm{CO}_{2}$ effluxes did not change between months but were twice as high outside solar panels than below solar panels $(\mathrm{p}<0.001)$.

\subsection{Effects of solar panels on plant communities}

Neither the species richness nor the total cover of plant community was significantly affected by the solar panels (Table 4). A marginally significant difference was detected for the ratio 'Sciaphile: Heliophile plants', being higher below than outside solar panels. The NMDS and PEMANOVA did not reveal any significant panel effect on plant community composition $(\mathrm{p}=0.3461$, Figure 3$)$. However, community composition was significantly different between the solar parks $(\mathrm{p}<0.001)$. No significant difference was detected between observation years (data not shown).

\section{Discussion}

Solar park (SP) construction reduced physical and chemical soil quality compared with semi-natural land cover types (forest and shrubland) but not biological soil quality. A change in soil temperature and $\mathrm{CO}_{2}$ effluxes also demonstrated a negative solar panel effect on soil microclimate and functioning. However, in early stages of plant succession following solar park construction, plant community composition below and outside solar panels was not significantly different.

\subsection{Effects of solar park construction on soil quality}

Soil quality assessments require the measurement of a wide range of physical, chemical, and biological properties involving a high complexity of potential analyses (Maurya et al. , 2020). In this study, we assessed soil quality using a multi-proxy approach including 21 soil properties. The reduction of the number of variables using PCA to group these properties allows an integrated evaluation of soil quality based on their main functions, such as infiltration and storage of water, soil fertility, plant reestablishment and soil organic matter and nutrient cycling. We found that two of three integrated sub-indicators and the general indicator of soil quality were lower in SP than in the other land cover types. 
Among the physical soil properties, the aggregate MWD was 1.5 times lower in the SP than in the seminatural land cover types. A low MWD may result in a low aggregate stability. Similarly, (Kabir et al. , 2017) showed that the MWD decrease in anthropogenic soils associated with a degraded vegetation. In our study, soil levelling and vegetation removal prior to SP construction may have decreased soil organic matter (SOM) content reducing MWD. By binding colloids and stabilizing soil structure, SOM plays a key role in soil physical properties and nutrient cycling (Six et al. , 2004). Telak and Bogunovic (2020) showed a decrease in $\mathrm{SOM}$ and MWD in a vineyard of Croatia after intensive and frequent tillage. Such mechanical disturbance for many years may have affected soil structure of the vineyard on which the studied SP (Roquefort des Corbières) was constructed. A lower SOM affects microbial activity and production of mucus resulting in a decrease of aggregates MWD and thus a soil more sensitive to erosion (Blavet et al. , 2009; Le Bissonnais et al. , 2018). The soil levelling and vegetation removal during SP construction may have increased surface runoff and soil erosion (Rabaia et al. , 2021). In our study, the effect of SP construction was not strong enough to change these physical soil properties. In contrast to our expectations, the SP construction did neither increase soil compaction nor decrease porosity compared to the abandoned vineyard. The past soil tillage in abandoned vineyard may have already degraded these properties before SP construction limiting effects of construction work.

Accordingly, overall physical soil quality of SP was lower than that of abandoned vineyard which was in turn lower than that of semi-natural land cover types. The physical soil quality index revealed that the construction of a SP increased the degradation of the physical soil quality of soils already degraded by land management (abandoned vineyard). In particular, the stability of the soil, key factor of soil functioning, was lower in SP than in abandoned vineyard. Soil restoration by revegetation may improve soil physical quality and functions of solar parks over initial vineyard conditions towards semi-natural land cover types (Hernandez et al. , 2019).

Soil chemical properties, such as total and organic carbon and total nitrogen are directly linked to soil fertility and plant growth (Krullet al. , 2004; Liu et al. , 2014). In our study, these properties showed lower values in anthropogenic soils than in semi-natural land cover types. Joimel et al. (2016) obtained similar results along a gradient from natural to anthropogenic habitats in which total carbon and nitrogen decreased significantly from forests to vineyard. Soil disturbance such as soil tillage in vineyard or construction activities increases mineralization of organic matter reducing organic C and N (Brantley \& Young, 2010). Accordingly, Choi et al. (2020) found a significantly lower C and N content in SP than in grassland soil. In our study, SP construction did not reduce neither $\mathrm{C}$ and $\mathrm{N}$ content nor soil chemical quality compared to degraded vineyard soil. Our results suggest that previous agricultural practices have strongly affected the soil chemical quality and that the construction of SP did not have an additional impact.

Soil microorganisms (i.e. bacteria and fungi) contribute actively to soil nutrient cycling (Schimel and Schaeffer, 2012). Thus, their genetic and physiologic characteristics are important indicators of ecosystem functioning such as nutrient cycling (Ranjard et al. , 2011). Microbiological soil properties showed differences between land cover types for fluorescein diacetate hydrolase (FDAse) activity and basal respiration. FDAse is an appropriate proxy to evaluate soil microbial activities because the ubiquitous esterase enzymes (lipase, protease, phosphatase) are involved in the hydrolysis of FDA (Schnürer \& Rosswall, 1982). In our study, the FDAse was two times lower in anthropogenic soils suggesting a reduction of microbiological activity and nutrient cycling. Soil basal respiration showed the same pattern confirming a degradation of soil functions compared to semi-natural soils (Sparling 1997). A lower rate of basal respiration may be the result of a lower organic carbon and nitrogen content (Horakova et al. 2020). Despite the reduction of these two microbial properties in anthropogenic soils, the microbiological soil quality index ( $\mathrm{mSiQ}$ ) was not significantly different between land cover types. Other microbiological properties (BM and phosphatase) mainly contributing to the first PCA axis were not affected by land cover type and thus overruled significant response variables in $\mathrm{mSiQ}$ calculation.

As a consequence of lower physical and chemical sub-indicators, the general indicator of soil quality was about three times lower in SP compared to semi-natural land cover types. Similarly, Zhang et al. (2019) found that 
the soil quality was about $50 \%$ higher in restored shrubland than in anthropogenic soils (cropland). The key processes involved in degradation of soil quality were soil tillage, partial topsoil removal increasing erosion (Quinton et al. , 2010) and organic matter mineralization. Reduced organic matter content and increase of soil compaction decrease water holding capacity (Mujdeciet al. , 2017) and soil stability (Simansky et al. , 2013).

\subsection{Effects of solar panels on vegetation, soil microclimate and $\mathrm{CO}_{2}$ effluxes}

Climatic conditions influence both soil microbial activities (Shaoet al. , 2018) and plant communities (GarcíaFayos \& Bochet, 2009). In our study, solar panels reduced the soil temperature in spring and in summer by about 5degC. Similarly, Armstrong et al. (2016) found a soil temperature reduction of $2 \operatorname{degC}$ under solar panels during the summer (UK). The lower temperature under solar panels was the direct effect of shading although night temperatures may be higher (Tanner et al. , 2020). Solar panels also intercept precipitation, and Tanner et al. (2020) found a significant reduction in soil humidity under solar panels in the Mojave desert. However, we did not find any significant soil humidity difference under solar panels and outside. The result may be explained by a lower evapotranspiration limiting humidity losses during drought periods as suggested by Tanner et al.(2020).

Mediterranean vegetation is dominated by heliophilous plants (Bagella \& Caria, 2012). So, we expected that light reduction by solar panels strongly affects plant communities. However, we did not find a significant effect of solar panels on plant community composition and structure. The effect of solar panels on the ratio of shadow-tolerant to heliophilous species was only marginally significant and no influence on plant species richness was detected. Other studies showed, however, a reduction in plant cover and species richness under solar panels resulting from lower germination and higher mortality (Armstrong et al. 2016). Protection against strong solar radiation and drought during Mediterranean summer may have compensated for reduction of light and precipitation in our study. Accordingly, Tanner et al. (2020) observed that in a desert plant richness was marginally greater under their solar panels than in the control. In our study, the absence of a solar panel effect on the vegetation may also be explained by the low age of our solar parks limiting differential effects on the vegetation. In early successional stages, the vegetation is dominated by ubiquitous annual species germinating and developing under a great variety of environmental conditions. Responses to the specific microclimate under solar panels may be slow in Mediterranean vegetation types (Coiffait-Gombault et al. , 2012; Kinzig et al. , 1999). Long-term monitoring is required to finally evaluate the influence of solar panels on plant communities.

Soil $\mathrm{CO}_{2}$ effluxes are driven by soil climate (Francioniet al. , 2020) and vegetation (Moinet et al. , 2019). In our study, soil respiration was highly affected by solar panels. Similarly, Armstrong et al. (2016) found a reduction of soil $\mathrm{CO}_{2}$ effluxes under solar panels. We detected a reduced $\mathrm{CO}_{2}$ efflux already in March. Since temperature is the major driver of soil respiration (Gonzalez-Ubierna \& Lai, 2019) the difference is probably the result of the warmer Mediterranean spring increasing solar panel effects. However, the reduction of $\mathrm{CO}_{2}$ effluxes under solar panels may also be the result of light reduction reducing plant growth and root respiration. A lower soil respiration is an indicator of lower litter decomposition and nutrient cycling suggesting that these ecosystem functions may be reduced under solar panels (Incerti et al. , 2011).

\subsection{Conclusions}

Physical, chemical, and global soil qualities were lower in solar park than in semi-natural land cover types. Clearing and grading the soil surface during solar park construction induced a strong degradation of soil physical quality, especially of soil structure, but did not disturb nor soil chemical quality neither global quality. Our study suggests that the solar parks should be constructed preferably on anthropogenic soils or that it must be accompanied by environmental reduction measures and ecological restoration. At our Mediterranean study sites, solar panels reduced both soil temperature and soil $\mathrm{CO}_{2}$ effluxes but not vegetation in the beginning of plant succession. These effects could, however, alter soil functions such as organic matter decomposition and nutrient cycles leading to disturb plant establishment and growth in the long term. Longterm monitoring including different seasons is required to evaluate the final response of soil properties and 
vegetation to solar panels.

Reference

Adeh EH, Selker JS, Higgins CW. 2018. Remarkable agrivoltaic influence on soil moisture, micrometeorology and water-use efficiency. Plos One 13 : e0203256. DOI: 10.1371/journal.pone.0203256

Anderson JP, Domsch KH. 1978. A physiological method for the quantitative measurement of microbial biomass in soils. Soil biology and biochemistry $10: 215-221$

Anderson T-H. 2003. Microbial eco-physiological indicators to asses soil quality. Agriculture, Ecosystems $\mathscr{E}$ Environment 98 : 285-293. DOI: 10.1016/S0167-8809(03)00088-4

Armstrong A, Ostle NJ, Whitaker J. 2016. Solar park microclimate and vegetation management effects on grassland carbon cycling.Environmental Research Letters 11 : 074016. DOI: 10.1088/1748$9326 / 11 / 7 / 074016$

Aubert G. 1978. Methodes d'analyses des sols: documents de travail tous droits reserves. Centre regional de documentation pedagogique

Bagella S, Caria MC. 2012. Diversity and ecological characteristics of vascular flora in Mediterranean temporary pools. Comptes Rendus Biologies 335 : 69-76. DOI: 10.1016/j.crvi.2011.10.005

Blavet D, De Noni G, Le Bissonnais Y, Leonard M, Maillo L, Laurent JY, Asseline J, Leprun JC, Arshad MA, Roose E. 2009. Effect of land use and management on the early stages of soil water erosion in French Mediterranean vineyards. Soil and Tillage Research 106 : 124-136. DOI: 10.1016/j.still.2009.04.010

Brantley ST, Young DR. 2010. Shrub expansion stimulates soil C and N storage along a coastal soil chronosequence. Global Change Biology 16 : 2052-2061. DOI: 10.1111/j.1365-2486.2009.02129.x

Bunemann EK, Bongiorno G, Bai Z, Creamer RE, De Deyn G, de Goede R, Fleskens L, Geissen V, Kuyper TW, Mader P, Pulleman M, Sukkel W, van Groenigen JW, Brussaard L. 2018. Soil quality - A critical review.Soil Biology and Biochemistry 120 : 105-125. DOI: 10.1016/j.soilbio.2018.01.030

Choi CS, Cagle AE, Macknick J, Bloom DE, Caplan JS, Ravi S. 2020. Effects of Revegetation on Soil Physical and Chemical Properties in Solar Photovoltaic Infrastructure. Frontiers in Environmental Science 8. DOI: $10.3389 /$ fenvs. 2020.00140

Coiffait-Gombault C, Buisson E, Dutoit T. 2012. Are old Mediterranean grasslands resilient to human disturbances? Acta Oecologica43 : 86-94. DOI: 10.1016/j.actao.2012.04.011

Costantini EAC, Branquinho C, Nunes A, Schwilch G, Stavi I, Valdecantos A, Zucca C. 2016. Soil indicators to assess the effectiveness of restoration strategies in dryland ecosystems. Solid Earth 7 : 397-414. DOI: https://doi.org/10.5194/se-7-397-2016

de Dato GD, De Angelis P, Sirca C, Beier C. 2010. Impact of drought and increasing temperatures on soil CO2 emissions in a Mediterranean shrubland (gariga). Plant and Soil 327 : 153-166. DOI: 10.1007/s11104009-0041-y

Francioni M, Trozzo L, Toderi M, Baldoni N, Allegrezza M, Tesei G, Kishimoto-Mo AW, Foresi L, Santilocchi R, D’Ottavio P. 2020. Soil Respiration Dynamics in Bromus erectus-Dominated Grasslands under Different Management Intensities. Agriculture 10 : 9. DOI: 10.3390/agriculture10010009

Garcia-Fayos P, Bochet E. 2009. Indication of antagonistic interaction between climate change and erosion on plant species richness and soil properties in semiarid Mediterranean ecosystems. Global Change Biology 15 : 306-318. DOI: https://doi.org/10.1111/j.1365-2486.2008.01738.x

Gonzalez-Ubierna S, Lai R. 2019. Modelling the effects of climate factors on soil respiration across Mediterranean ecosystems. Journal of Arid Environments 165 : 46-54. DOI: 10.1016/j.jaridenv.2019.02.008 
Green VS, Stott DE, Diack M. 2006. Assay for fluorescein diacetate hydrolytic activity: Optimization for soil samples. Soil Biology and Biochemistry 38 : 693-701. DOI: 10.1016/j.soilbio.2005.06.020

Gresta F, Cristaudo A, Onofri A, Restuccia A, Avola G. 2010. Germination response of four pasture species to temperature, light, and post-harvest period. Plant Biosystems 144: 849-856. DOI: $10.1080 / 11263504.2010 .523549$

Hernandez RR, Armstrong A, Burney J, Ryan G, Moore-O'Leary K, Diedhiou I, Grodsky SM, Saul-Gershenz L, Davis R, Macknick J, Mulvaney D, Heath GA, Easter SB, Hoffacker MK, Allen MF, Kammen DM. 2019. Techno-ecological synergies of solar energy for global sustainability.Nature Sustainability 2 : 560-568. DOI: 10.1038/s41893-019-0309-z

Hernandez RR, Hoffacker MK, Murphy-Mariscal ML, Wu GC, Allen MF. 2015. Solar energy development impacts on land cover change and protected areas. Proceedings of the National Academy of Sciences112 : 13579-13584. DOI: 10.1073/pnas.1517656112

Horakova E, Pospisilova L, Vlcek V, Mensik L. 2020. Changes in the soil's biological and chemical properties due to the land use.Soil and Water Research 15 : 228-236. DOI: 10.17221/44/2019-SWR

Huang Q, Akinremi OO, Rajan RS, Bullock P. 2004. Laboratory and field evaluation of five soil water sensors. Canadian Journal of Soil Science. DOI: 10.4141/S03-097

Husson F, Josse J, Le S, Mazet J. 2020. FactoMineR: Multivariate Exploratory Data Analysis and Data Mining .

Incerti G, Bonanomi G, Giannino F, Rutigliano FA, Piermatteo D, Castaldi S, De Marco A, Fierro A, Fioretto A, Maggi O, Papa S, Persiani AM, Feoli E, De Santo AV, Mazzoleni S. 2011. Litter decomposition in Mediterranean ecosystems: Modelling the controlling role of climatic conditions and litter quality. Applied Soil Ecology 49 : 148-157. DOI: 10.1016/j.apsoil.2011.06.004

Joimel S, Cortet J, Jolivet CC, Saby NPA, Chenot ED, Branchu P, Consales JN, Lefort C, Morel JL, Schwartz C. 2016. han. Science of The Total Environment 545-546 : 40-47. DOI: 10.1016/j.scitotenv.2015.12.035

Joimel S, Schwartz C, Hedde M, Kiyota S, Krogh PH, Nahmani J, Peres G, Vergnes A, Cortet J. 2017. Urban and industrial land uses have a higher soil biological quality than expected from physicochemical quality.Science of The Total Environment 584-585 : 614-621. DOI: 10.1016/j.scitotenv.2017.01.086

Julve P. 2020. Baseflor. Index botanique, ecologique et chorologique de la flore de France.

Kabir EB, Bashari H, Mosaddeghi MR, Bassiri M. 2017. Soil aggregate stability and organic matter as affected by land-use change in central Iran. Archives of Agronomy and Soil Science 63 : 1823-1837. DOI: 10.1080/03650340.2017.1308492

Karlen DL, Mausbach MJ, Doran JW, Cline RG, Harris RF, Schuman GE. 1997. Soil Quality: A Concept, Definition, and Framework for Evaluation (A Guest Editorial). Soil Science Society of America Journal61 : 4-10. DOI: https://doi.org/10.2136/sssaj1997.03615995006100010001x

Kassambara A, Mundt F. 2020. factoextra: Extract and Visualize the Results of Multivariate Data Analyses

Keeney D, Nelson D. 1983. Nitrogen -inorganic forms. Methods of Soil Analysis. Part 2. Chemical and Microbiological Properties. John Wiley \& Sons, Ltd, i-xxiv. DOI: 10.2134/agronmonogr9.2.2ed.frontmatter

Kemper WD, Rosenau RC. 2018. Aggregate Stability and Size Distribution.Methods of Soil Analysis . John Wiley \& Sons, Ltd, 425-442. DOI: 10.2136/sssabookser5.1.2ed.c17

Khare P, Goyal DK. 2013. Effect of high and low rank char on soil quality and carbon sequestration. Ecological Engineering52 : 161-166. DOI: 10.1016/j.ecoleng.2012.12.101 
Kinzig AP, Levin SA, Dushoff J, Pacala S. 1999. Limiting Similarity, Species Packing, and System Stability for Hierarchical Competition-Colonization Models. The American Naturalist153 : 371-383. DOI: $10.1086 / 303182$

Krull ES, SKJEMSTAD JO, BALDOCK JA. 2004. Functions of soil organic matter and the effect on soil properties .

Lampurlanes J, Cantero-Martinez C. 2003. Soil Bulk Density and Penetration Resistance under Different Tillage and Crop Management Systems and Their Relationship with Barley Root Growth. Agronomy Journal 95 : 526-536. DOI: https://doi.org/10.2134/agronj2003.5260

Le Bissonnais Y, Prieto I, Roumet C, Nespoulous J, Metayer J, Huon S, Villatoro M, Stokes A. 2018. Soil aggregate stability in Mediterranean and tropical agro-ecosystems: effect of plant roots and soil characteristics. Plant and Soil 424 : 303-317. DOI: 10.1007/s11104-017-3423-6

Liu Z, Zhou W, Shen J, Li S, Ai C. 2014. Soil quality assessment of yellow clayey paddy soils with different productivity. Biology and Fertility of Soils 50 : 537-548. DOI: 10.1007/s00374-013-0864-9

Maurya S, Abraham JS, Somasundaram S, Toteja R, Gupta R, Makhija S. 2020. Indicators for assessment of soil quality: a mini-review.Environmental Monitoring and Assessment 192 : 604. DOI: 10.1007/s10661020-08556-z

Moinet GYK, Midwood AJ, Hunt JE, Rumpel C, Millard P, Chabbi A. 2019. Grassland Management Influences the Response of Soil Respiration to Drought. Agronomy-Basel 9 : 124. DOI: 10.3390/agronomy9030124

Mujdeci M, Simsek S, Uygur V. 2017. The Effects of Organic Amendments on Soil Water Retention Characteristics Under Conventional Tillage System.Fresenius Environmental Bulletin 26 : 4075-4081

Muller G, Gastner M. 1971. The'Karbonat-Bombe', a simple device for the determination of carbonate content in sediment, soils, and other materials. Neues Jahrbuch fur Mineralogie-Monatshefte10 : 466-469

Mulvaney RL. 1996. Nitrogen-Inorganic Forms. Methods of Soil Analysis . John Wiley \& Sons, Ltd, 1123-1184. DOI: 10.2136/sssabookser5.3.c38

Murphy DJ, Horner RM, Clark CE. 2015. The impact of off-site land use energy intensity on the overall life cycle land use energy intensity for utility-scale solar electricity generation technologies. Journal of Renewable and Sustainable Energy 7 : 033116. DOI: 10.1063/1.4921650

Novara A, Armstrong A, Gristina L, Semple KT, Quinton JN. 2012. Effects of soil compaction, rain exposure and their interaction on soil carbon dioxide emission. Earth Surface Processes and Landforms37 : 994-999. DOI: $10.1002 /$ esp.3224

Olmstead LB, Alexander LT, Middleton HE. 1930. A pipette method of mechanical analysis of soils based on improved dispersion procedure.

Ong S, Campbell C, Denholm P, Margolis R, Heath G. 2013. Land-Use Requirements for Solar Power Plants in the United States . National Renewable Energy Lab. (NREL), Golden, CO (United States). DOI: 10.2172/1086349

Quinton JN, Govers G, Van Oost K, Bardgett RD. 2010. The impact of agricultural soil erosion on biogeochemical cycling. Nature Geoscience 3 : 311-314. DOI: 10.1038/ngeo838

Rabaia MKH, Abdelkareem MA, Sayed ET, Elsaid K, Chae K-J, Wilberforce T, Olabi AG. 2021. Environmental impacts of solar energy systems: A review.Science of The Total Environment 754 : 141989. DOI: 10.1016/j.scitotenv.2020.141989

Raich JW, Tufekciogul A. 2000. Vegetation and soil respiration: Correlations and controls. Biogeochemistry 48 : 71-90. DOI: 10.1023/A:1006112000616 
Raiesi F, Salek-Gilani S. 2020. Development of a soil quality index for characterizing effects of land-use changes on degradation and ecological restoration of rangeland soils in a semi-arid ecosystem. Land Degradation $\& 3$ Development 31 : 1533-1544. DOI: https://doi.org/10.1002/ldr.3553

Ranjard L, Dequiedt S, Jolivet C, Saby NPA, Thioulouse J, Harmand J, Loisel P, Rapaport A, Fall S, Simonet P, Joffre R, Boure NC-P, Maron P-A, Mougel C, Martin MP, Toutain B, Arrouays D, Lemanceau P. 2011. Biogeography of Soil Microbial Communities: A Review and a Description of the Ongoing French National Initiative. Sustainable Agriculture Volume 2 857-865. DOI: 10.1007/978-94-007-0394-0_37

Romero-Diaz A, Ruiz-Sinoga JD, Robledano-Aymerich F, Brevik EC, Cerda A. 2017. Ecosystem responses to land abandonment in Western Mediterranean Mountains. CATENA 149 : 824-835. DOI: 10.1016/j.catena.2016.08.013

Rutgers M, Schouten AJ, Bloem J, Eekeren NV, Goede RGMD, Akkerhuis GAJMJ, Wal AV der, Mulder C, Brussaard L, Breure AM. 2009. Biological measurements in a nationwide soil monitoring network. European Journal of Soil Science 60 : 820-832. DOI: https://doi.org/10.1111/j.1365-2389.2009.01163.x

Saetre P. 1998. Decomposition, Microbial Community Structure, and Earthworm Effects Along a BirchSpruce Soil Gradient. Ecology79 : 834-846. DOI: 10.1890/0012-9658(1998)079[0834:DMCSAE]2.0.CO;2

Saiya-Cork KR, Sinsabaugh RL, Zak DR. 2002. The effects of long term nitrogen deposition on extracellular enzyme activity in an Acer saccharum forest soil. Soil Biology and Biochemistry 34 : 1309-1315. DOI: 10.1016/S0038-0717(02)00074-3

Scarpare FV, van Lier Q de J, de Camargo L, Pires RCM, Ruiz-Correa ST, Bezerra AHF, Gava GJC, Dias CTS. 2019. Tillage effects on soil physical condition and root growth associated with sugarcane water availability.Soil $\& 5$ Tillage Research 187 : 110-118. DOI: 10.1016/j.still.2018.12.005

Schimel J, Schaeffer SM. 2012. Microbial control over carbon cycling in soil. Frontiers in Microbiology 3 . DOI: $10.3389 /$ fmicb.2012.00348

Schnurer J, Rosswall T. 1982. Fluorescein Diacetate Hydrolysis as a Measure of Total Microbial Activity in Soil and Litter. Applied and Environmental Microbiology 43 : 1256-1261

Shao P, He H, Zhang X, Xie H, Bao X, Liang C. 2018. Responses of microbial residues to simulated climate change in a semiarid grassland.Science of the Total Environment 644 : 1286-1291. DOI: 10.1016/j.scitotenv.2018.07.055

Simansky V, Bajcan D, Ducsay L. 2013. The effect of organic matter on aggregation under different soil management practices in a vineyard in an extremely humid year. Catena 101 : 108-113. DOI: $10.1016 /$ j.catena.2012.10.011

Six J, Bossuyt H, Degryze S, Denef K. 2004. A history of research on the link between (micro)aggregates, soil biota, and soil organic matter dynamics. Soil and Tillage Research 79 : 7-31. DOI: 10.1016/j.still.2004.03.008

Sparling G. 1997. Soil microbial biomass, activity and nutrient cycling as indicators of soil health. Biological indicators of soil health $97-119$

Tabatabai MA, Bremner JM. 1969. Use of p-nitrophenyl phosphate for assay of soil phosphatase activity. Soil biology and biochemistry 1 : 301-307

Tanner KE, Moore-O'Leary KA, Parker IM, Pavlik BM, Hernandez RR. 2020. Simulated solar panels create altered microhabitats in desert landforms.Ecosphere 11 : e03089. DOI: 10.1002/ecs2.3089

Team RC. 2020. R: A language and environment for statistical computing.

Telak LJ, Bogunovic I. 2020. Tillage-induced impacts on the soil properties, soil water erosion, and loss of nutrients in the vineyard (Central Croatia). Journal of Central European Agriculture21 : 589-601. DOI: 
Velasquez E, Lavelle P, Andrade M. 2007. GISQ, a multifunctional indicator of soil quality. Soil Biology and Biochemistry39 : 3066-3080. DOI: 10.1016/j.soilbio.2007.06.013

Wall DH, Bardgett RD, Behan-Pelletier V, Herrick JE, Jones TH, Six J, Strong DR, Putten WH van der, Ritz K. 2012. Soil Ecology and Ecosystem Services . OUP Oxford

Yang L, Liu N, Ren H, Wang J. 2009. Facilitation by two exotic Acacia: Acacia auriculiformis and Acacia mangium as nurse plants in South China.Forest Ecology and Management 257 : 1786-1793. DOI: 10.1016/j.foreco.2009.01.033

Yin R, Kardol P, Thakur MP, Gruss I, Wu G-L, Eisenhauer N, Schaedler M. 2020. Soil functional biodiversity and biological quality under threat: Intensive land use outweighs climate change. Soil Biology \& Biochemistry 147 : 107847. DOI: 10.1016/j.soilbio.2020.107847

Zhang Y, Xu X, Li Z, Liu M, Xu C, Zhang R, Luo W. 2019. Effects of vegetation restoration on soil quality in degraded karst landscapes of southwest China. Science of The Total Environment 650 : 2657-2665. DOI: $10.1016 /$ j.scitotenv.2018.09.372

Zou CB, Barnes PW, Archer S, McMurtry CR. 2005. Soil moisture redistribution as a mechanism of facilitation in savanna tree-shrub clusters. Oecologia $145: 32-40$. DOI: 10.1007/s00442-005-0110-8

Table

Table 1 Environmental and technical characteristics of solar parks.

\begin{tabular}{|c|c|c|c|}
\hline & La Calade & Pouzols-Minervois & $\begin{array}{l}\text { Roquefort des } \\
\text { Corbières }\end{array}$ \\
\hline Altitude (m) & 77 & 100 & 62 \\
\hline Slope $(\%)$ & 5 & 5 & 5 \\
\hline $\begin{array}{l}\text { Temperature (annual } \\
\text { mean, }{ }^{\circ} \mathrm{C} \text { ) }\end{array}$ & 15.5 & 13.6 & 15.5 \\
\hline $\begin{array}{l}\text { Precipitation (annual } \\
\text { mean, mm) }\end{array}$ & 557 & 648 & 557 \\
\hline $\begin{array}{l}\text { Sunshine duration } \\
\text { (annual mean, hours) }\end{array}$ & 2465 & 2119 & 2324 \\
\hline Soil texture & Loamy soil & Loamy soil & Loamy soil \\
\hline $\begin{array}{l}\text { Land cover before } \\
\text { construction }\end{array}$ & Shrubland & $\begin{array}{l}\text { Abandoned Vineyard and } \\
\text { shrubland }\end{array}$ & Abandoned Vineyard \\
\hline $\begin{array}{l}\text { Commissioning of the } \\
\text { SP }\end{array}$ & 2011 & 2014 & 2016 \\
\hline Maximum power (Kwc) & 5102 & 4950 & 11152 \\
\hline Area of the PK (ha) & 8.5 & 10.7 & 16 \\
\hline
\end{tabular}

Table 2: Soil physical, chemical, and microbiological properties in each type of land cover. Mean values with standard errors in parentheses. Different letters indicate significant differences between land cover types (significant P-values in bold). BD: bulk density, WC: water content; WHC : water holding capacity; MWD : mean weight diameter; OC : organic carbon; TC: Total carbon, TN: total nitrogen; BR : basal respiration; $\mathrm{MB}$ : microbial biomass; qCO2 : metabolic quotient; FDAse : Fluorescein diacetate hydrolase.

\begin{tabular}{llllll}
\hline & Properties & Pinewood & Shrubland & Abandoned Vineyards & Solar pa \\
\hline Physical & Sand (\%) & $35.13(5.07)^{\mathrm{a}}$ & $45.91(8.96)^{\mathrm{ab}}$ & $47.78(4.34)^{\mathrm{b}}$ & $42.68(2$ \\
& Silt (\%) & $47.32(8.63)^{\mathrm{a}}$ & $35.81(6.67)^{\mathrm{ab}}$ & $33.16(2.97)^{\mathrm{b}}$ & $35.97(1$
\end{tabular}




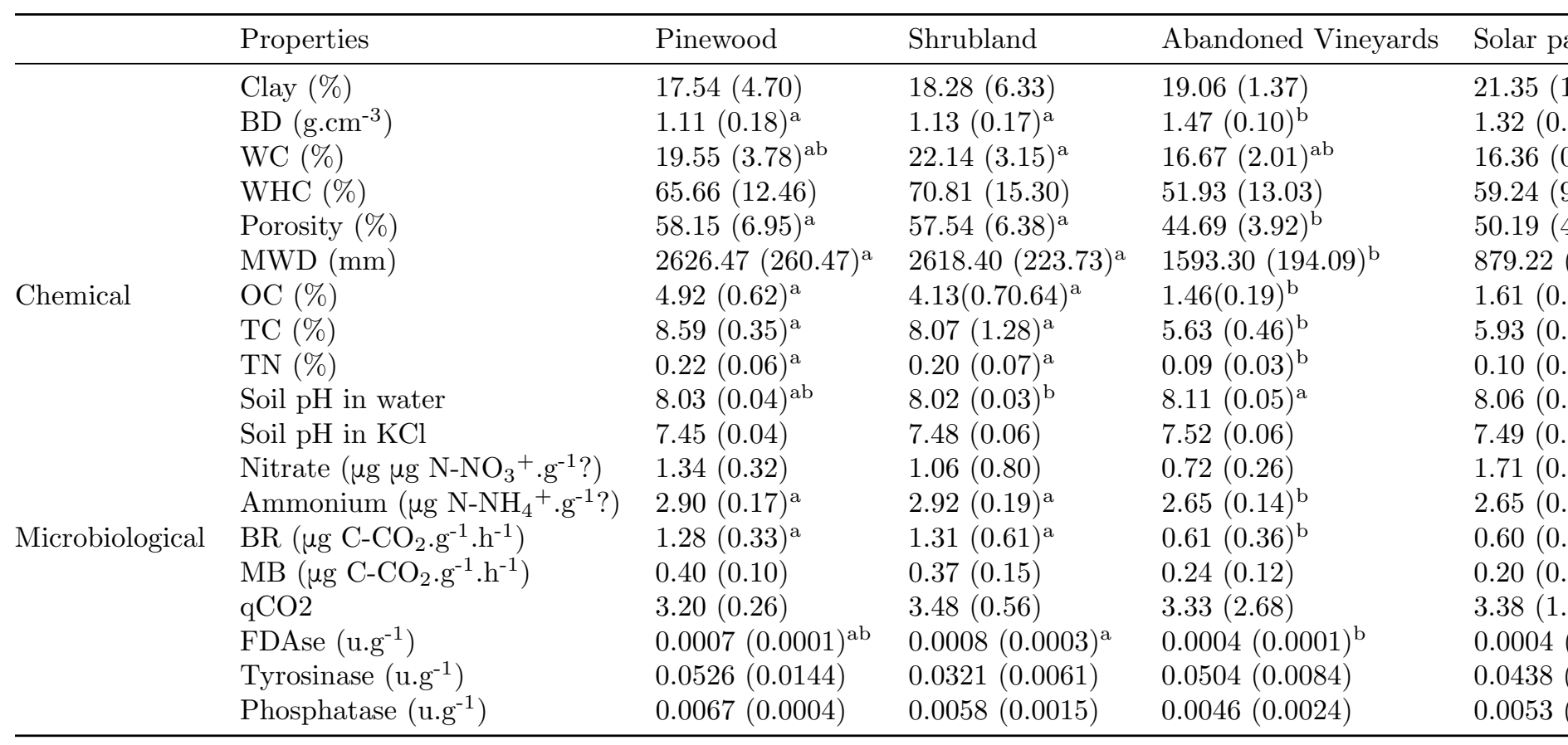

\begin{tabular}{llll}
\hline Parameters & Below solar panels & Outside solar panels & $\mathrm{p}$ \\
\hline Species richness & $12.56(5.92)$ & $13.25(5.49)$ & 0.29 \\
Total cover (\%) & $351.2(165.12)$ & $379.97(183.31)$ & 0.22 \\
Hemi-heliophilous: & $0.12(0.14)$ & $0.10(0.10)$ & 0.09 \\
Heliophilous ratio & & & \\
\hline
\end{tabular}

Table 3: Effects of solar panels on plant communities. Mean values with standard errors in parentheses.
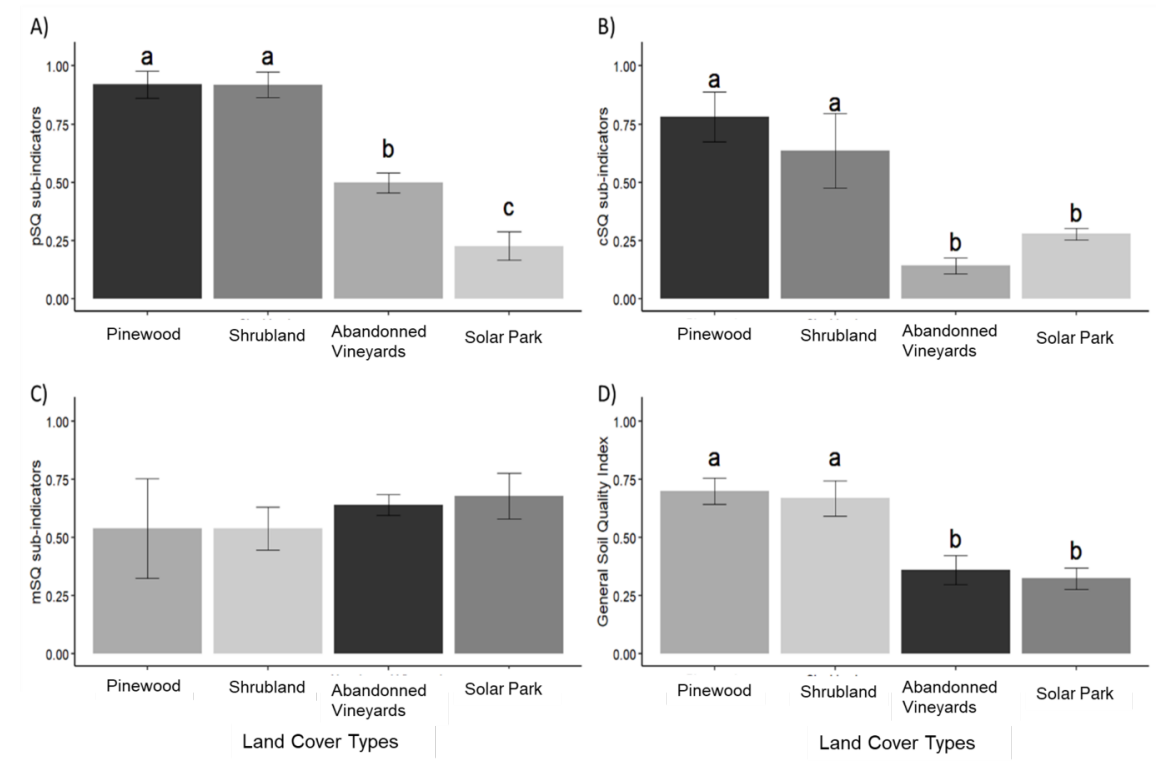
Figures
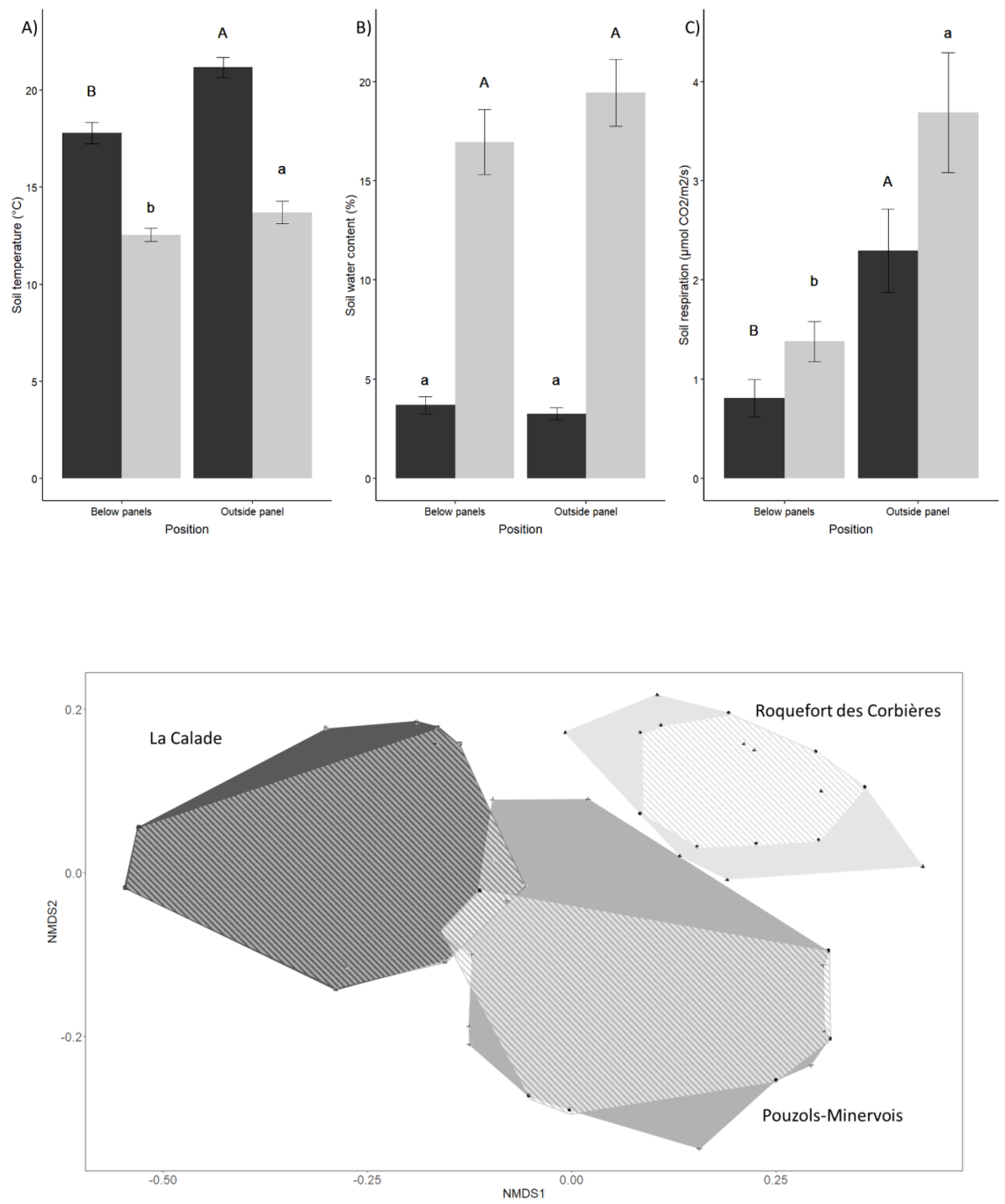

Figure legend :

Figure 1 : Sub-indicators of soil physical (A), chemical (B), and microbiological (C) quality and general soil quality indicator (D) for different types of land cover. Error bars are means $+/$ - standard error. Different letters indicate significant differences $(\mathrm{p}<0.05)$.

Figure 2: Soil temperature (A), water content (B) and $\mathrm{CO}_{2}$ effluxes in March (black bars) and June (grey gars) below and outside solar panels. Error bars are means +/- standard error; different capital and lowercase letters indicate significant differences between under and outside panels in March and June, respectively. Black and grey bars represent the value of March and June, repectively.

Figure 3: NMDS plot with polygons indicating the plant species composition of the three solar parks under (hatched polygon) and outside (solid polygon) solar panels, NMDS stress: 0.084 . 

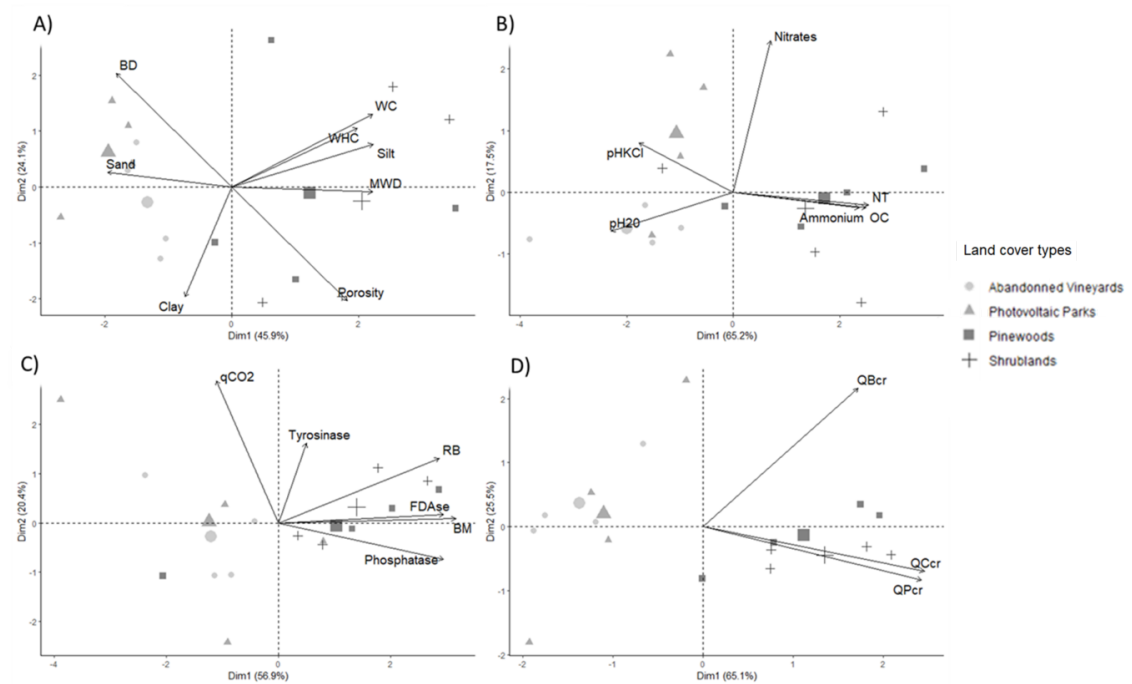

Appendice 1 Standardised principal components analysis (PCA) biplot (axes I and II) showing relationships between land cover types and soil properties of each soil quality indicator. A) physical indicator, B) chemical indicator C) microbiological indicator D) General indicator of soil quality with QBcr :soil microbiological sub-indicator quality, QPcr: soil physical quality sub-indicator, B)soil chemical quality sub-indicator. 